PENGARUH DANA KAPITASI DALAM MENINGKATKAN KUALITAS LAYANAN PADA FASILITAS KESEHATAN TINGKAT PERTAMA DI YOGYAKARTA

\title{
Indah Shofiyah
}

Universitas Ahmad Dahlan

Email: indah.shofiyah@act.uad.ac.id

Indra Bastian

Universitas Gadjah Mada

Email: indra_bastian@yahoo.com

\begin{abstract}
This study aims to investigate the effect of capitation in improving the service quality at primary care in Yogyakarta province. Variables in this research are incentives and the proportion of capitation. This research uses financial and performance primary care reports which collected from Health Agency in Yogyakarta Province. Data was successfully processed were 62 reports. The results of this research show that incentives and the proportion of capitation statistically influence in improving service quality, on the other side proportion of capitation funds statistically does not strengthen relationship between incentives and service quality.
\end{abstract}

Keywords: Capitation, Capitation Payment System, Incentives, Proportion of Capitation, Service Quality, Primary Care.

\section{PENDAHULUAN}

Perawatan kesehatan merupakan faktor penting untuk mencapai tujuan umum dari pelayanan kesehatan. Salah satu hal yang dibutuhkan untuk mencapai tujuan kesehatan adalah pemberian layanan yang berkualitas (Jegers et al., 2002). Permasalahan yang sering dihadapi oleh beberapa negara dalam bidang pelayanan kesehatan adalah permintaan layanan kesehatan dari tahun ke tahun selalu mengalami peningkatan (Jacob et al., 2014; Majeed, 2002). Pemerintah dituntut untuk menyediakan akses ke layanan kesehatan yang berkualitas dan dapat diakses oleh semua kalangan masyarakat, sementara pemerintah juga dihadapkan pada keterbatasan anggaran kesehatan (Andoh-Adjei et al., 2016).

Meningkatnya tuntutan tersebut mengharuskan pemerintah untuk melakukan pengelolaan dana kesehatan melalui berbagai strategi, salah satunya dengan mereformasi sistem pembayaran penyedia layanan agar sistem kesehatan tetap selaras dengan cita-cita Universal Health Coverage/UHC (Jegers et al., 2002). Hal lain yang bisa dilakukan untuk mengelola dana kesehatan selain mereformasi sistem pembiayaan sebagai strategi untuk mengatasi permasalahan tersebut pemerintah harus menentukan bagaimana membayar penyedia layanan untuk menyelaraskan kepentingan mereka dengan kepentingan pasien (Robinson, 2001). 
Indah Shofiyah, Indra Bastian | Pengaruh Dana Kapitasi dalam Peningkatan Kualitas Layanan ...

Beberapa negara di dunia menggunakan sistem pembayaran kapitasi yaitu sistem pembayaran pada fasilitas kesehatan tingkat pertama (FKTP) untuk pasien rawat jalan yang diberikan oleh (Badan Penyelenggara Jaminan Sosial Kesehatan (BPJS-Kes) dan besarannya didasarkan pada jumlah peserta yang terdaftar di FKTP tersebut. Inggris menerapkan formula penyesuaian risiko penuh untuk menghitung tingkat yang dikapitalisasi. Denmark menyesuaikan tingkat penggunaannya berdasarkan usia dan jenis kelamin, Thailand ditentukan oleh pemerintah dan tidak memiliki formula penyesuaian risiko dan beberapa negara di Eropa Tengah menggunakan kapitasi yang disesuaikan dengan usia dan jenis kelamin untuk membayar perawatan primer (Scott, Sivey, and Ouakrim, 2011). Ghana memperkenalkan pembayaran kapitasi untuk layanan perawatan primer di bawah skema asuransi kesehatan nasional sebagai proyek percontohan pada tahun 2012. Tidak seperti banyak negara lain, tingkat kapitasi di Ghana tidak disesuaikan dengan risiko (Andoh-Adjei et al., 2016).

Penelitian yang dilakukan oleh Jacob and Paul (2014) mengenai pembayaran kapitasi, menunjukkan bahwa sistem kapitasi mampu mempromosikan penggunaan sumber daya secara efisien dan menekan pengeluaran pada biaya layanan kesehatan dengan catatan tingkat pembayaran kapitasi memadai, jadwal pembayaran kapitasi tepat waktu dan mekanisme pembayaran untuk penggantian biaya layanan baik. Sistem pembayaran kapitasi bagi tenaga kesehatan akan mempengaruhi perilakunya, karena tenaga kesehatan akan menerima pembayaran yang tetap setiap bulannya sesuai anggota yang berada dalam daftar anggotanya. Hal tersebut akan menyebabkan tenaga kesehatan mengurangi pelayanan yang mahal dan berlebihan. Selain itu kapitasi merupakan metode yang mampu mengembalikan kepercayaan masyarakat terhadap pemerintah dalam memberikan pelayanan dan mengembalikan kepercayaan masyarakat terhadap penyedia layanan (Goodson et al., 2001).

Pelayanan kesehatan dibentuk oleh berbagai pemangku kepentingan, seperti penyedia layanan, pembuat kebijakan, pembayar dan pemasok. Oleh karena itu prioritas pemangku kepentingan pada layanan kesehatan perlu dipertimbangkan dalam setiap upaya untuk menilai, mengukur, dan meningkatkan kualitas pelayanan kesehatan (Hudelson et al., 2008; Muntlin et al., 2006). Di Indonesia, pemerintah bekerja sama dengan Badan Penyelenggara Jaminan Sosial (BPJS) Kesehatan untuk memperbaiki pelaksanaan pemberian layanan kesehatan melalui program Jaminan Kesehatan Nasional (JKN). Program tersebut mengharuskan setiap warga negara untuk menjadi peserta JKN dan membayar biaya kesehatan setiap bulannya kepada BPJS dengan presentase atau nominal tertentu, kecuali bagi masyarakat yang tidak mampu, maka akan dibayarkan oleh pemerintah sepenuhnya. Sebagai bentuk pertanggungjawaban pemerintah maka dana iuran kesehatan dari masyarakat tersebut harus digunakan dan dialokasikan sesuai dengan kebutuhan. Agar tujuan untuk memperbaiki kualitas layanan kesehatan dapat terwujud.

Hubungan antara pihak puskesmas dan pihak BPJS serta masyarakat bisa dijelaskan dengan menggunakan teori keagenan. BPJS dan masyarakat bertindak sebagai prinsipal sementara pihak puskesmas bertindak sebagai agen yang akan mengelola dana kapitasi. Agar agen tetap bekerja sesuai dengan keinginan prinsipal, maka prinsipal akan 
Indah Shofiyah, Indra Bastian | Pengaruh Dana Kapitasi dalam Peningkatan Kualitas Layanan ...

melakukan berbagai strategi pemberian insentif dan pengawasan.

Beberapa strategi mengenai struktur pembayaran kesehatan telah dibahas dalam penelitian sebelumnya seperti kapitasi, fee for service, risk- adjusted pay for performance, bundled payment dalam menghasilkan kualitas layanan yang baik (Pine, Meimban, and Pine, 2010; Ninot et al., 2011). Berdasarkan penelitian (Pine, Meimban, and Pine, 2010; Ninot et al., 2011) yang membandingkan antar metode pembayaran yang paling efektif dalam mengurangi biaya tanpa harus menurunkan kualitas layanan, menunjukkan bahwa kapitasi merupakan metode yang dapat meningkatkan kualitas layanan. Akan tetapi penelitian lain Young, Beckman, Baker (2012) menunjukkan bahwa ternyata strategi umum yang biasanya digunakan untuk meningkatkan kualitas pelayanan kesehatan adalah sistem pembiayaan pay for performace, atau fee for services. Hal itu dikarenakan tenaga kesehatan membutuhkan insentif keuangan agar dapat bekerja secara produktif, efisien dan memberikan pelayanan dengan kualitas yang sesuai dengan harapan pasien.

Sebagai tindak lanjut atas komitmen untuk meningkatkan kualitas layanan. Pemerintah mengeluarkan Peraturan Presiden No. 32 Tahun 2014 tentang Pengelolaan dan Pemanfaatan Dana Kapitasi JKN pada Fasilitas Kesehatan Tingkat Pertama milik Pemerintah Daerah. Peraturan tersebut mengamanatkan bahwa dana kapitasi akan dimanfaatkan untuk pembayaran jasa pelayanan kesehatan (insentif) dan dukungan biaya operasional pelayanan kesehatan (Kementrian kesehatan 2016). Insentif atau pemberian imbalan merupakan hal yang mampu menumbuhkan motivasi bagi tenaga kesehatan untuk memberikan layanan yang berkualitas kepada masyarakat (Sancoko, 2010).

Terdapat banyak wacana yang mengatakan bahwa pembagian beban kerja di berbagai FKTP tidak adil, hal tersebut menyebabkan kecemburuan antar tenaga kesehatan, kecemburuan itu disebabkan oleh perbedaan beban kerja dan pemberian insentif. Hasil riset yang dilakukan oleh Likke Purti (2016) menyatakan bahwa terjadi ketimpangan nominal pendapatan antar profesi di FKTP. Ketimpangan tersebut disebabkan oleh proporsi tunjangan daerah dan jasa pelayanan yang diperoleh dari dana kapitasi. Hal lain yang turut menyebabkan ketimpangan pendapatan bagi tenaga kesehatan adalah antara pendapatan yang diperoleh dari dana kapitasi melalui FKTP dan pendapatan yang diperoleh dari praktik mandiri di luar FKTP. Ketimpangan pendapatan tersebut menyebabkan motivasi tenaga kerja berkurang.

Penelitian Pearson (2013) mengatakan bahwa layanan yang berkualitas juga dinilai dengan kesediaan tenaga kesehatan untuk memberikan edukasi mengenai pola hidup yang sehat, namun kesedian untuk memberikan edukasi kepada pasien tersebut tidak akan dilakukan oleh tenaga kesehatan jika tenaga kesehatan tidak memiliki motivasi untuk meningkatkan kualitas layanan. Oleh sebab itu adanya insentif diharapkan mampu untuk menumbuhkan motivasi pegawai kesehatan untuk memberikan pelayanan yang berkualitas. Dalam literatur manajemen, model teoritis standar mengenai efek motivasi dari insentif keuangan tidak secara eksplisit memasukkan variabel yang terkait dengan sikap individu terhadap insentif. Untuk menilai apakah model semacam itu perlu disempurnakan, maka perlu dilakukan penyelidikan apakah para profesional lebih atau kurang responsif terhadap insentif keuangan atas dasar bagaimana mereka merasakan 
Indah Shofiyah, Indra Bastian | Pengaruh Dana Kapitasi dalam Peningkatan Kualitas Layanan ...

insentif relatif terhadap nilai-nilai profesional mereka sendiri. Lebih jauh lagi, dari perspektif praktis, pembuat kebijakan dan manajer membutuhkan panduan empiris tentang kegunaan dari mengadopsi program kapitasi dalam organisasi profesional.

Kualitas pelayanan tidak hanya diukur melalui pemberian pelayanan yang intangible. Ketersediaan sarana dan prasarana fisik juga merupakan faktor penting yang menunjang kualitas layanan kesehatan (Parasuraman and Berry, 1990). proporsi pendapatan dana kapitasi yang besar akan dapat mencukupi keperluan peralatan kesehatan dan sarana penunjang lainnya (Hasan, 2017). Sehingga proporsi pendapatan dana kapitasi diharapkan akan mampu menunjang kualitas layanan kesehatan.

Penelitian mengenai penggunaan dana kapitasi ini dilakukan di DIY karena dinilai mempunyai dasar yang kuat dalam penyelenggaraan pemerintahan, Yogyakarta juga merupakan provinsi yang maju dan mudah beradaptasi dengan berbagai hal baru, termasuk dalam hal penggunaan dana kapitasi. Pemerintah Daerah Yogyakarta berkomitmen untuk menyelenggarakan pelayanan kesehatan secara benar sesuai dengan aturan dalam deklarasi Yogya Sehat Berintegritas. Deklarasi tersebut juga menitikberatkan pada pemberian pelayanan puublik di bidang kesehatan yang optimal dan seluruh masyarakat terlayani dengan baik.

Dana kapitasi yang diberikan oleh BPJS Kesehatan kepada FKTP belum dapat meningkatkan kualitas layanan, hal tersebut diduga karena penggunaan yang belum tepat dan kurangnya motivasi para tenaga perawat dalam memberikan layanan kepada masyarakat (Palino, 2017). Literatur menunjukkan bahwa motivasi seseorang dalam bekerja dipengaruh oleh banyak faktor seperti jabatan, insentif keuangan, tekanan, lingkungan serta ketersediaan sarana dan prasarana yang dapat menunjang kinerja karyawan. Dana kapitasi merupakan pendapatan puskesmas yang paling besar namun hasil penelitian (Hasan, 2017) masih menunjukkan tidak ada peningkatan kualitas pelayanan, hal tersebut diduga alokasi dana kapitasi yang tidak tepat dan pemberian insentif yang tidak sesuai dengan beban kerja. Dalam konteks pemerintah daerah Yogyakarta belum ada yang meneliti. Oleh sebab itu perlu dilakukan penelitian di Yogyakarta karena karakteristik FKTP yang berbeda.

\section{TINJAUAN PUSTAKA}

\section{Teori Keagenan}

Teori keagenan (Jensen dan Meckling, 1976) menjelaskan hubungan antara prinsipal dan agen. Prinsipal adalah pihak yang mendelegasikan pekerjaan kepada pihak lain yang biasa disebut dengan agen. Agen diasumsikan memiliki tujuan yang tidak sepenuhnya konsisten dengan prinsipal dan berusaha untuk memaksimalkan keuntungannya sendiri. Dengan kata lain, agen cenderung mengabaikan tanggung jawab yang ditugaskan untuk kepentingan pribadi jika ini dapat dilakukan tanpa menimbulkan konsekuensi keuangan. Agen ini juga diasumsikan sebagai risk averse sehubungan dengan pendapatan. Oleh karena itu, agen akan berusaha melakukan kegiatan yang memaksimalkan utilitasnya bahkan ketika kegiatan ini mengorbankan kepentingan prinsipalnya. 
Indah Shofiyah, Indra Bastian | Pengaruh Dana Kapitasi dalam Peningkatan Kualitas Layanan ...

Sistem dalam pemberian layanan kesehatan meliputi hubungan FKTP, BPJS, dan masyarakat yang membentuk hubungan antara prinsipal dan agen. Hubungan tersebut dijelaskan menggunakan teori keagenan yang secara sederhana mengasumsikan bahwa dalam kehidupan sosial terdapat kontrak-kontrak yang disepakati. Hubungan tersebut diatur oleh kontrak yang berisi apa saja yang harus dilakukan oleh agen dan apa saja yang harus dilakukan oleh prinsipal sebagai balas jasanya. Pihak BPJS sebagai prinsipal menggunakan berbagai perangkat seperti sistem kontrak, regulasi, dan menjalankan mekanisme monitoring untuk memastikan bahwa FKTP memberikan pelayanan kesehatan yang berkualitas.

Masalah utama bagi prinsipal adalah bagaimana struktur yang semestinya dibangun agar agen melakukan pekerjaan sesuai dengan keinginan prinsipal. Untuk mengatasi masalah ini, prinsipal dapat mengikuti salah satu dari dua pendekatan umum. Salah satu pendekatan yang dapat digunakan oleh prinsipal adalah menentukan dan memantau aktivitas kerja agen. Pendekatan ini mengasumsikan prinsipal mampu menentukan terlebih dahulu kegiatan yang dapat memantau perilaku agen untuk mengidentifikasi penyimpangan yang dilakukan agen. Pengembangan dan penerapan sistem pemantauan bisa mahal. Selain itu, kondisi asimetri informasi sering diasumsikan bahwa agen memiliki pemahaman yang lebih baik dan informasi yang lebih lengkap tentang kegiatan kerja yang mendasarinya daripada prinsipal. Jadi, meskipun prinsipal mampu memantau input agen, namun tidak dapat menentukan aktivitas agen karena prinsipal tidak memiliki cukup pemahaman tentang tugas. Dalam keadaan seperti itu, pengembangan sistem pemantauan yang efektif mungkin sangat mahal atau bahkan tidak mungkin (Eisenhardt, 1989).

Pendekatan lain yang juga dapat digunakan adalah prinsipal memberikan insentif bagi agen agar target kinerja yang diinginkan oleh prinsipal tercapai. (Bonner dan Sprinkle, 2002; Eisenhardt, 1989; Prendergast, 2002). Jadi dapat dilihat bahwa dari perspektif teori agensi, insentif merupakan upaya dari pihak prinsipal agar agen bekerja sesuai dengan tujuan yang diinginkan prinsipal. Insentif keuangan dapat digunakan untuk memotivasi individu untuk bekerja sesuai dengan tujuan yang ditetapkan dalam hal arah dan durasi organisasi (Bonner dan Sprinkle, 2002). Nilai insentif uang mampu mempengaruhi perilaku agen karena dapat memenuhi kebutuhan barang dan jasa bagi agen (Mitchell dan Mickel, 1999; Osterloh dan Frey, 2000; Stajkovic dan Luthans, 2001). Selain itu, uang memiliki nilai simbolis karena dikaitkan dengan atribut seperti status sosial, kekuasaan, dan kebebasan (Mitchell dan Mickel, 1999).

\section{Pengembangan Hipotesis dan Rerangka Penelitian}

\section{Insentif dan Kualitas Pelayanan Kesehatan}

Dana yang diterima dari BPJS dikelola oleh masing-masing FKTP untuk dialokasikan ke dalam dua hal, yaitu pembayaran jasa pelayanan kesehatan dan dukungan biaya operasional pelayanan kesehatan (Permenkes RI No. 21/2016). Jasa pelayanan diberikan kepada tenaga kesehatan dan tenaga non kesehatan yang melakukan pelayanan pada FKTP. 
Indah Shofiyah, Indra Bastian | Pengaruh Dana Kapitasi dalam Peningkatan Kualitas Layanan ...

Alokasi dana kapitasi yang digunakan untuk membayar jasa layanan kesehatan adalah sekurang-kurangnya 60\% dari seluruh dana kapitasi yang diterima oleh FKTP, sementara selisih dari dana yang digunakan untuk membayar biaya layanan tersebut dialokasikan untuk membiayai dukungan biaya operasional pelayanan kesehatan, yang meliputi biaya obat, alat kesehatan dan bahan medis habis pakai, serta biaya operasional pelayanan kesehatan lainnya yaitu untuk belanja operasional barang dan belanja modal (Permenkes RI No.21 Tahun 2016).

Pemerintah selalu berupaya untuk mengurangi konflik kepentingan antara pihak pemberi dana dan pengelola dana. Mekanisme pembayaran atas jasa layanan menjadi salah satu metode yang harus diperbaiki institusi pemberi layanan kesehatan untuk bisa mengurangi konflik tersebut, sehingga kualitas layanan dapat ditingkatkan (Milstein, 2000). Besar kemungkinan bahwa kualitas layanan akan dipengaruhi oleh besarnya pembayaran atas jasa yang diberikan oleh dokter dan tenaga perawat. Seperti yang dicontohkan di beberapa lembaga pelayanan kesehatan di Amerika bahwa proyek pembayaran untuk kinerja akan memberikan motivasi kepada pemberi layanan dalam memberikan pelayanan terbaik terhadap masyarakat.

Meskipun insentif telah digunakan secara luas di berbagai organisasi untuk meningkatkan kinerja pegawainya, namun sistem pemberian insentif ini masih banyak mengalamai perdebatan. Banyak studi empiris yang menguji hubungan insentif keuangan dengan kinerja dan menunjukkan hasil yang sangat beragam, misalnya Rosenthal dan Frank, 2006; Bonner dan Sprinkle, 2002). Berdasarkan penelitian tersebut muncul berbagai pertanyaan, apakah insentif keuangan dapat memperbaiki kinerja dan meningkatkan kualitas layanan.

Kemungkinan besar kualitas layanan akan dipengaruhi oleh besarnya pembayaran jasa (insentif keuangan). Hasil penelitian sebelumnya (Bonner dan Sprinkle, 2002) menunjukkan bahwa insentif memiliki efek motivasi bagi para profesional yang melakukan pekerjaan mereka dengan kontrol eksternal yang relatif sedikit. Oleh sebab itu hipotesis 1 dirumuskan sebagai berikut:

H1 : Insen \tif berpengaruh positif terhadap kualitas pelayanan kesehatan

\section{Proporsi pendapatan dan kualitas layanan}

Besarnya pendapatan yang diperoleh setiap puskesmas tidak sama, tergantung dari jumlah peserta yang terdaftar di puskesmas tersebut. Penelitian yang dilakukan oleh Hasan (2017) menujukkan bahwa proporsi pendapatan dana kapitasi dari seluruh pendapatan primary care akan berpengaruh terhadap kualitas pelayanan yang diberikan oleh pihak penyedia layanan.

Panandu (2016) yang menyebutkan bahwa sarana dan prasarana yang tidak dapat menunjang pelayanan kesehatan di puskesmas disebabkan oleh beberapa permasalahan, di antaranya kurangnya alat-alat kesehatan dan fasilitas kesehatan terutama di ruang rawat inap. Puskesmas dengan jumlah kapitasi yang besar memiliki kemampuan untuk memenuhi kebutuhan operasionalnya dan dapat memenuhi kebutuhan sarana dan prasara fisik. 
Indah Shofiyah, Indra Bastian | Pengaruh Dana Kapitasi dalam Peningkatan Kualitas Layanan ...

Ditinjau dari teori keagenan, salah satu asumsinya mengatakan bahwa pada dasarnya manusia itu memiliki sifat risk averse/menghindari risiko (Steinhart, 1989). Ketika dana kapitasi yang diberikan oleh pihak BPJS besar, namun agen tidak dapat meningkatkan kualitas pelayanannya, maka agen akan dinilai gagal mengelola dana kapitasi dan mengakibatkan pemberian dana kapitasi tidak dilakukan secara penuh untuk bulan berikutnya. Keadaan tersebut tentu saja tidak diinginkan oleh pihak agen. Oleh karena itu agen akan berusaha untuk melakukan kinerja terbaiknya untuk tetap mempertahankan proporsi dana kapitasi yang tinggi. Penelitiann sebelumnya menunjukkan hasil bahwa proporsi dana kapitasi akan meningkatkan kualitas layanan (Pearson, 2013) maka, hipotesis yang di ajukan dalam penelitian ini adalah:

H2 :Proporsi pendapatan dana kapitasi berpengaruh positif terhadap peningkatan kualitas pelayanan kesehatan

\section{Insentif, proporsi pendapatan dana kapitasi dan kualitas pelayanan kesehatan}

Pemberian pelayanan yang berkualitas merupakan tujuan utama dari setiap organisasi, agar tujuan tersebut dapat tercapai, maka berbagai kebijakan perlu dilakukan oleh organisasi untuk meningkatkan kinerja karyawan dalam memberikan pelayanan (Handoko, 2001). Salah satu caranya adalah dengan memberikan insentif sesuai dengan kinerjanya.

Hubungan antara insentif dan kualitas layanan kemungkinan diperkuat oleh proporsi dana kapitasi yang besar. Penelitian yang dilakukan oleh Hasan (2017) memberikan bukti bahwa terbatasnya dana kapitasi pada puskesmas dengan peserta JKN yang sedikit, menyebabkan puskesmas tidak mampu melengkapi sarana yag penting di puskesmas, misalnya laboratorium. Akibatnya puskesmas tersebut harus merujuk pemeriksaan laboratorium ke puskesmas lain yang memiliki proporsi dana kapitasi lebih besar.

Peningkatan pendapatan dari dana kapitasi memungkinkan FKTP untuk dapat memberikan insentif yang lebih besar bagi tenaga kesehatan. Jika pendapatan FKTP dari dana nonkapitasi diasumsikan tidak mengalami perubahan nominal yang signifikan, maka dapat dinyatakan bahwa peningkatan proporsi pendapatan kapitasi pada FKTP dapat meningkatkan insentif yang diterima oleh tenaga kesehatan. Peningkatan insentif tersebut dapat dikaitkan dengan motivasi tenaga kesehatan yang dapat mengarah pada peningkatan kualitas layanan kesehatan. Berdasarkan itu maka dapat diduga bahwa proporsi pendapatan dana kapitasi dapat memperkuat pengaruh insentif pada kualitas pelayanan kesehatan.

Berdasarkan penjelasan di atas, maka hipotesis tiga yang diajukan dalam penelitian ini adalah:

H3 : Proporsi pendapatan dana kapitasi memperkuat hubungan antara insentif dan kualitas layanan kesehatan pada fasilitas kesehatan tingkat pertama 
Indah Shofiyah, Indra Bastian | Pengaruh Dana Kapitasi dalam Peningkatan Kualitas Layanan ...

\section{Rerangka Penelitian}

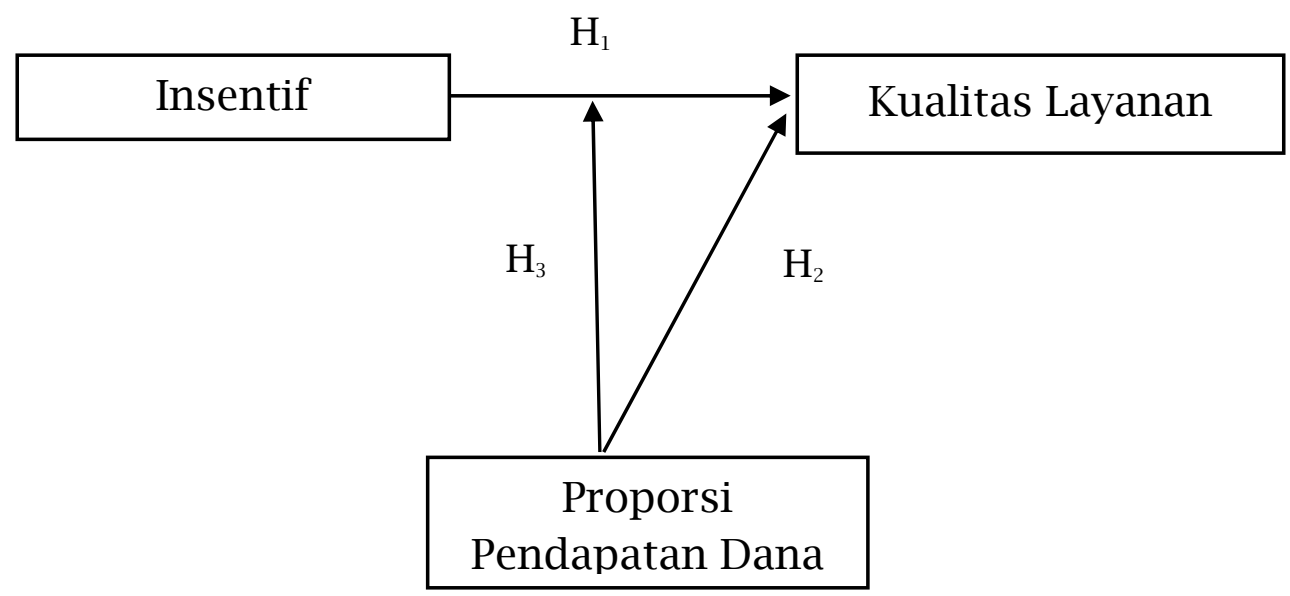

Gambar 1. Rerangka Penelitian

\section{METODE PENELITIAN}

Jenis data yang digunakan dalam penelitian ini merupakan data sekunder, yaitu berupa laporan keuangan puskesmas yang dan laporan mengenai kualitas pelayanan kesehatan masyarakat. Data mengenai indeks kualitas layanan kesehatan masyarakat diperoleh dari puskesmas. Data mengenai insentif dilihat dari laporan keuangan pada pos pengeluaran belanja layanan jasa dan proporsi pendapatan dana kapitasi dihitung dari persentase dana kapitasi atas total pendapatan puskesmas.

Puskesmas yang dipilih sebagai sampel adalah puskesmas yang sesuai dengan kriteria yang ditentukan oleh peneliti dan membuat laporan keuangan seperti yang wajibkan oleh Dinas Kesehatan terkait. Kriteria tersebut diantaranya membuat laporan keuangan dan laporan kinerja pada tahun 2018. Didalam laporan kinerja tersebut puskesmas harus menyajikan nilai manajemen mutu, manajemen obat dan pelayanan kesehatan. Data diambil melalui hand collected dengan datang langsung ke dinas kesehatan.

Pengujian yang dilakukan dengan menggunakan uji regresi model regresi harus memenuhi persyaratan BLUE (Best Linear Unbiased Estimator) sebelum dilakukan uji hipotesis. Seperti yang dijelaskan oleh (Ghozali 2011), uji asumsi klasik dilakukan pada seluruh model persamaan regresi yang mencerminkan model penelitian. Uji asumsi klasik pada penelitian ini terdiri dari empat macam uji yaitu uji normalitas, uji multikolinearitas, uji autokorelasi, uji heteroskedastisitas.

Model regresi berganda yang digunakan dalam penelitian ini yaitu:

$\mathrm{SQ}=\alpha+\beta 1 \mathrm{I}+\beta 2 \mathrm{PD}+\beta 1 \mathrm{BJ} * \beta 2 \mathrm{PD}+\varepsilon$

\section{Keterangan:}

SQ = Kualitas Layanan

$\mathrm{PD}=$ Proporsi Pendapatan

I $=$ Insentif 
Indah Shofiyah, Indra Bastian | Pengaruh Dana Kapitasi dalam Peningkatan Kualitas Layanan ...

\section{METODE PENELITIAN}

\section{Definisi Operasional dan Pengukuran Variabel}

Variabel dependen pada penelitian ini adalah kualitas layanan kesehatan. Definisinya merujuk pada Parasuraman (1990) yang mendefinisikan kualitas layanan sebagai kualitas atau mutu merupakan suatu keadaan dinamis yang berhubungan dengan jasa, produk, proses, dan lingkungan yang memenuhi atau melebihi harapan dari pelanggan, dalam hal ini pasien. Kualitas meliputi setiap aspek dari suatu organisasi dan merupakan suatu harapan yang harus dipenuhi bagi pasien. Pasien akan merasa senang apabila harapan untuk memperoleh pelayanan yang baik terpenuhi, mereka merasa bahwa dirinya telah mendapatkan nilai terbaik dan ingin memastikan dana yang mereka bayarkan kepada BPJS telah dikelola dengan baik, dan mereka merasa bangga akan kinerja puskesmas (agen) yang berkualitas tinggi.

Pengukurannya dilihat dari indeks kualitas layanan yang disusun dan dilaporkan oleh puskesmas tersebut dalam laporan kinerja. Dalam laporan kinerja tersebut mencakup beberapa hal, diantaranya skor layanan kesehatan, manajemen obat dan manajemen mutu.

Variabel independen dalam penelitian ini adalah insentif yang dalam hal ini dilihat dari belanja layanan jasa merujuk pada definisi yang ada di undang-undang bahwa belanja layanan jasa adalah pengeluaran yang dibayarkan kepada tenaga kesehatan sebagai balasan atas ajasa yang diberikan. Pengukurannya dilakukan dengan melihat besaran belanja yang dikeluarkan untuk belanja jasa pelayanan dalam laporan keuangan.

Variable independen selanjutnya adalah proporsi dana kapitasi yang merujuk pada definisi Pearson (2013) bahwa proporsi dana kapitasi merupakan persentase pendapatan dapi kapitasi dalam semua pendapatan yang diterima oleh puskesmas yang diukur dari persentase kapitasi dari total pendapatan yang tertera dalam laporan keuangan.

\section{Statistik Deskriptif}

Statistik deskriptif dilakukan dengan tujuan untuk memberikan gambaran atau deskripsi data yang digunakan dalam penelitian. Dalam penelitian ini variabel yang digunakan adalah kualitas layanan (SQ), Insentif (In), dan Proporsi Pendapatan dana Kapitas (Prop). Gambaran umum sampel dengan variabel kualitas layanan, insentif dan proporsi pendapatan dana kapitasi dapat dilihat pada tabel 1 statistik deskriptif berikut:

Tabel 1. Hasil statistik deskriptif

$\begin{array}{crrrrr}\text { Variabel } & \text { N } & \text { Minimum } & \text { Maksimum } & \text { Mean } & \text { Std. Deviasi } \\ \text { SQ } & 62 & 46 & 98 & 87 & 12 \\ \text { In } & 62 & 9.447 .000 & 2.021 .292 .900 & 568.533 .658 & 573.964 .656 \\ \text { Prop } & 62 & 66 & 98,7 & 88,69 & 22,04\end{array}$

Sumber: Hasil olah data 
Indah Shofiyah, Indra Bastian | Pengaruh Dana Kapitasi dalam Peningkatan Kualitas Layanan ...

\section{Hasil Uji Asumsi Klasik}

\section{Uji Normalitas Data}

Uji normalitas digunakan untuk menguji hubungan antara variabel dependen dan variabel independen dalam model regresi berdistribusi normal atau tidak. Normalitas dapat dideteksi dengan menggunakan analisis grafik dan pengujian statistik. Dalam penelitian ini peneliti mendeteksi dengan menggunakan one-sample kolmogorov-Smirnov Test. Dikatakan berdistribusi normal jika nilai signifikansi dari pengujian one-sample kolmogorov-Smirnov lebih besar dari a $=5 \%(0,05)$. Uji normalitas dilakukan pada semua sampel puskesmas.

Uji normalitas dilakukan pada semua sampel dengan variabel SQ (kualitas layanan), In (insentif), dan Prop (proporsi pendapatan dana kapitasi). Hasil pengujiannya dapat dilihat pada tabel berikut:

Tabel 2. Hasil Uji Normalitas

\begin{tabular}{lc}
\hline \multicolumn{1}{c}{ Keterangan } & Unstandarized Residual \\
\hline Jumlah Sampel & 62 \\
Nilai Kolmogorov- Smirnov Z & 0,835 \\
Asymp. Sig. (2. Tailed) & 0,488 \\
\hline
\end{tabular}

Sumber: Hasil olah data

Hasil pengujian tersebut, dapat dilihat bahwa residual memiliki signifikansi lebih besar dari 0,05. Hal tersebut menunjukkan bahwa residual berdistribusi normal dan memenuhi asumsi normalitas.

\section{Uji Multikolinearitas Data}

Uji multikolinearitas bertujuan untuk mengetahui apakah setiap variabel independen saling berhubungan secara linear, uji multikolinearitas juga dapat digunakan untuk mengetahui apakah hubungan antar variabel independen yang terdapat dalam penelitian memiliki hubungan yang sempurna atau hampir sempurna. Untuk melihat apakah suatu model terdapat gejala multikolinearitas, bisa dilihat dari nilai tolerance $>0,1$ dan nilai $\mathrm{VIF}<10$.

Hasil uji multikolinearitas dalam penelitian ini dapat dilihat dalam tabel 3 berikut:

Tabel 3. Hasil Uji Multikolinearitas

\begin{tabular}{lcc}
\hline \multicolumn{1}{c}{ Variabel } & \multicolumn{2}{c}{ Collinearity Statistics } \\
& Tolerance & VIF \\
\hline Insentif & 0,158 & 6,336 \\
Proporsi Pendapatan Dana Kapitasi & 0,299 & 3,342 \\
Interksi & 0,113 & 8,870 \\
\hline
\end{tabular}

Sumber: Hasil olah data 
Indah Shofiyah, Indra Bastian | Pengaruh Dana Kapitasi dalam Peningkatan Kualitas Layanan ...

\section{Uji heteroskedastisitas}

Uji heteroskedastisitas biasanya digunakan untuk menguji kesamaan varians dari residual satu pengamatan ke pengamatan yang lain. Pengujian yang dilakukan untuk mengetahui gejala heteroskedastisitas dalam model penelitian ini yaitu dengan menggunakan uji Glejser. Hasil uji Glesjer dapat dilihat pada tabel 4 berikut:

Tabel 4. Hasil Uji Glesjer

\begin{tabular}{lll}
\hline Variabel Independen & Koefisien & Signifikansi \\
\hline Insentif & 0,656 & 0,842 \\
Proporsi Pendapatan Dana Kapitasi & 0,317 & 0,854 \\
Interaksi & $-1,523$ & 0,739 \\
\hline
\end{tabular}

Sumber: Hasil olah data

Tabel di atas merupakan tabel untuk hasil uji Glejser yang berguna untuk mendeteksi adanya gejala heteroskedastisitas, berdasarkan hasil pengujian tersebut tidak terdapat satupun variabel yang mempengaruhi variabel dependen absolut residual secara signifikan, sehingga dapat disimpulkan bahwa model tersebut tidak terdapat gejala heteroskedastisitas.

\section{Hasil Uji Hipotesis}

Pengujian hipotesis dalam penelitian ini dilakukan dengan analisis regresi moderasi dengan bantuan software SPSS, pengujian ini bisa dilakukan jika semua persyaratan asumsi klasik terpenuhi.

\section{Insentif Berpengaruh Terhadap Kualitas Layanan Kesehatan}

Hipotesis pertama dalam penelitian ini adalah insentif berpengaruh terhadap peningkatan kualitas layanan kesehatan. Hasil pengujian hipotesis 1 menggunakan analisis regresi dapat dilihat pada tabel 5 berikut:

Tabel 5. Hasil Uji Hipotesis

\begin{tabular}{llll}
\hline Variabel & T hitung & signifikansi & Keterangan \\
\hline Insentif & 2,802 & 0,007 & Terdukung \\
Proporsi Pendapatan & 2,918 & 0,005 & Terdukung \\
Interaksi & $-2,848$ & 0,006 & Tidak terdukung \\
\hline
\end{tabular}

Sumber: Hasil olah data

Pada tabel di atas dapat dilihat bahwa nilai signifikansi dari 0,007 atau $<0,05$ hal ini menunjukkan bahwa secara statsistik insentif berpengaruh positif dalam meningkatkan kualitas layanan di FKTP. 
Indah Shofiyah, Indra Bastian | Pengaruh Dana Kapitasi dalam Peningkatan Kualitas Layanan ...

\section{Proporsi Pendapatan Dana Kapitasi Berpengaruh Terhadap Kualitas Layanan Kesehatan}

Hipotesis kedua dalam penelitian ini adalah proporsi pendapatan dana kapitasi berpengaruh terhadap peningkatan kualitas layanan kesehatan. Hasil pengujian hipotesis 2 dapat dilihat dari hasil regresi pada tabel 5 bahwa nilai signifikansi untuk proporsi pendpaatan dana kapitasi sebesar 0,005 atau $<0,05$. Hal ini menunjukkan bahwa hipotesis 2 terdukung, berarti proporsi pendapatan dana kapitasi berpengaruh terhadap kualitas layanan kesehatan pada fasilitas kesehatan tingkat pertama di provinsi Daerah Istimewa Yogyakarta.

\section{Proporsi penggunaan dana kapitasi memperkuat pengaruh insentif dan kualitas layanan}

Hipotesis ketiga dalam penelitian ini adalah proporsi penggunaan dana kapitasi memperkuat pegaruh insentif dan peningkatan kualitas layanan. Pengujian dilakukan dengan menggunakan regresi linear moderasi. Hasil pengujian hipotesis tiga dapat dilihat dari tabel hasil regresi menunjukkan singnifikansi 0,006 atau $<0,05$, dengan demikian hipotesis yang mengatakan bahwa proporsi pendapatan dana kapitasi memperkuat hubungan antara insentif dan kualitas layanan secara statistik tidak terdukung, karena memiliki nilai koefisien beta $-2,848$.

\section{Diskusi dan Pembahasan}

\section{Hipotesis 1}

Berdasarkan pengujian hipotesis pertama dapat disimpulkan bahwa variabel insentif berpengaruh positif terhadap peningkatan kualitas layanan kesehatan pada fasilitas kesehatan tingkat pertama. Hasil ini menunjukkan bahwa tenaga kesehatan di puskesmas akan termotivasi dan meningkatkan kinerjanya ketika diberikan insentif. Dalam konteks pemerintah Yogyakarta kepala puskesmas telah cukup bijak dalam memberikan pembagian dana kapitasi jasa pelayanan, baik tenaga medis, paramedis, honorer atau tenaga non kesehatan di puskesmas (Laporan Kinerja Puskesmas Sleman, 2018). Sistem tersebut bertujuan untuk meminimalkan konflik kepentingan diantara pegawai dan konflik antara agen dan prinsipal. Sehingga pengaturan yang baik dan adil dalam pembagian insentif tersebut berhasil meningkatkan kualitas layanan pada puskesmas di DI Yogyakarta.

Sesuai dengan yang dikatakan oleh Atkinson, Banker, Kaplan (2000) bahwa insentif keuangan merupakan cara yang paling efektif untuk memotivasi dan memperbaiki kinerja pegawai. Sejalan dengan penelitian yang dilakukan oleh Bonner (2002) Insentif keuangan akan membuat seseorang berusaha untuk meningkatkan kemampuan yang dibutuhkan dalam meningkatkan performanya di suatu organisasi, sehinngga penghargaan yang akan diterimanya di masa depan akan lebih besar. Young (2012) juga menemukan hasil yang sejalan, bahwa insentif keuangan berperan sebagai pengendalian eksteral yang memiliki dampak motivasi untuk berlaku profesional dan sesuai standar yang telah ditetapkan organisasi di Provinsi DIY. 
Indah Shofiyah, Indra Bastian | Pengaruh Dana Kapitasi dalam Peningkatan Kualitas Layanan ...

\section{Hipotesis 2}

Berdasarkan pengujian pada hipotesis 2, hasil statistik menunjukkan bahwa proporsi pendapatan dana kapitasi mmeningkatkan kualitas layanan pada FKTP di DIY. Hal ini sesuai dengan salah satu asumsi dalam teori keagenan, bahwa beberapa individu memiliki sifat menghindari risiko (risk averse). Pihak pemberi dana mengharapkan bahwa adanya dana kapitasi yang besar, pengelolaan dana tersebut dilakukan dengan baik agar dapat memberikan pelayanan yang prima kepada masyarakat. Sifat bawaan manusia yang risk averse akan takut jika manajemen tidak mampu mengelola dana kapitasi dengan baik, dan tidak dapat meningkatkan kualitas pelayanan, karena hal tersebut akan berakibat pada pengurangan proporsi dana kapitasi untuk periode berikutnya.

Hasil ini berbeda dari penelitian Pearson (2013) yang menunjukkan bahwa tidak terdapat perbedaan kualitas layanan meskipun proporsi dana kapitasi yang diperoleh oleh FKTP bervariasi. Hasil ini memperkuat penelitian Hasan (2017) yang mengatakan bahwa salah satu kendala untuk memperbaiki kualitas layanan adalah kecilnya jumlah dana yang ada di puskesmas. Apalagi dana kapitasi merupakan pendapatan paling besar dari puskesmas. Jadi hampir semua aktivitas puskesmas didanai oleh dana kapitasi. Dalam konteks Indonesia, pendapatan dana kapitasi menjadi pendapatan puskesmas yang paling besar (Hasan, 2017). Sehingga proporsinya akan menentukan kemampuan puskesmas dalam memenuhi kebutuhan operasionalnya. Kekurangan sarana dan prasarana yang menunjang pemberian layanan yang berkualitas akan bisa dipenuhi dengan dana kapitasi yang tinggi.

\section{Hipotesis 3}

Berdasarkan hasil pengujian yang dilakukan pada hipotesis 3 menunjukan bahwa proporsi pendapatan dana kapitasi tidak memperkuat hubungan antara insentif dan kualitas layanan. Hal ini bisa jadi disebabkan adanya sifat bawaan manusia (Bonner, sprinkle, 2002), dalam penelitiannya Bonner dan Sprinkle (2002) mengatakan bahwa sifat dasar manusia akan mempengaruhi hubungan antara insentif keuangan dan kinerja. Sifat dasar manusia tersebut antara lain pengetahuan, kemampuan, motivasi instrinsik.

Manusia juga memiliki kecenderungan untuk mengutamakan self interestnya masing-masing dan kecenderungan untuk mengejar keuntungan lain yang bersifat non keuangan misalnya waktu luang, beban kerja yang sedikit. Jika keadaan ini yang terjadi maka setinggi apapun insentif yang diberikan dengan proporsi pendapatan yang besar maka tidak akan mempengaruhi peningkatan kualitas layanan fasilitas kesehatan tingkat pertama.

Dalam konteks Yogyakarta, proporsi dana kapitasi tidak memperkuat hubungan antara insentif dan kualitas layanan, hal tersebut dimungkinkan dana kapitasi tidak sepenuhnya dialokasikan pada pemberian insentif pada agen, namun juga dialokasikan pada pembelian sarana dan prasarana lain yang juga menunjung kualitas layanan (Laporan Keuangan Puskesmas, 2018). Penelitian mengenai dana kapitasi ini kemungkinan akan mendapatkan hasil yang berbeda jika dilakukan pada puskesmas yang memiliki 
Indah Shofiyah, Indra Bastian | Pengaruh Dana Kapitasi dalam Peningkatan Kualitas Layanan ...

pendapatan dari non kapitasi lebih besar. Karena kebutuhan dan operasional puskesmas akan dibiayai oleh pendapatan lain di luar dana kapitasi.

Jika dalam penelitian Pearson (2013) yang menguji pengaruh proporsi pendapatan dana kapitasi terhadap peningkatan kualitas layanan tidak menunjukkan hasil yang signifikan. Berbeda dengan hasil penelitian ini dikarenakan situasi dan sistem yang berbeda, pendapatan puskesmas di Yogyakarta rata-rata bergantung pada dana kapitasi. Jadi kapitasi mempunyai peran yang sangat besar dalam membiayai kegiatan dan operasional puskesmas. Bagian ini menyajikan hasil penelitian.

Uji F yang dihasilkan dalam model penelitian ini dapat dilihat pada Tabel 6 berikut:

Tabel 6. Uji F

\begin{tabular}{ccl}
\hline Model & F & Sig. \\
\hline 1 & 7,316 &, $000^{\mathrm{b}}$ \\
\hline
\end{tabular}

Berdasarkan Tabel 6 dapat diketahui bahwa uji F menghasilkan F hitung sebesar 7,316. Dengan nilai signifikansi sebesar $0.000<0.05$.

Tabel 7. Koefisien Determinasi

$\begin{array}{lrrrr}\text { Model } & \mathrm{R} & \mathrm{R} \text { Square } & \text { Adjusted R Square } & \text { Std. Error of the Estimate } \\ 1 & , 524^{\mathrm{a}} & , 275 & , 237 & 9,619\end{array}$

Berdasarkan Tabel 7 dalat diketahui bahwa nilai korelasi menunjukkan seberapa besar pengaruh variable independen terhadap variable dependen, besarnya nilai korelasi adalah 0.524 yang berarti bahwa hubungan variabel independen dan dependen adalah erat yaitu $52.4 \%$.

Nilai R Square sebesar 0.275 yang berarti bahwa sebesar 27,5\% variabel kualitas layanan dijelaskan oleh insentif dan proporsi dana kapitasi.

\section{KESIMPULAN, KETERBATASAN, DAN SARAN}

Hasil pengujian menunjukkan bahwa insentif memiliki pengaruh yang signifikan dalam peningkatan kualitas layanan pada fasilitas kesehatan tingkat pertama di Daerah Istimewa Yogyakarta. Begitu pula dengan proporsi pendpaatan dana kapitasi yang berpengaruh signifikan terhadap peningkatan kualitas pelayanan. Namun besarnya proporsi dana kapitasi tidak memperkuat hubungan antara insentif dan kualitas layanan.

Perluasan untuk penelitian selanjutnya dapat dikembangkan dengan memperluas objek penelitian, atau mengklaster pendapatan dana kapitasi tiap-tiap puskesmas, sehingga perbedaan ditiap level dapat diketahui seberapa besar peningkatannya terhadap kualitas pelayanan. Selain itu penelitian selanjutnya juga dapat menambahkan variabel lain yang mungkin mempengaruhi peningkatan kualitas pelayanan kesehatan. Penelitian 
Indah Shofiyah, Indra Bastian | Pengaruh Dana Kapitasi dalam Peningkatan Kualitas Layanan ...

ini kemungkinan akan memperoleh hasil yang berbeda jika dilakukan pada FKTP dengan pendapatan dana non kapitasi lebih tinggi dari pendapatan kapitasi.

Penelitian ini berkontribusi pada bidang teoretis dengan memberikan masukan mengenai alokasi penggunaan dana kapitasi yang lebih efektif dalam meningkatkan kualitas layanan. Dalam kondisi pengawasan eksternal rendah, dana kapitasi akan lebih dapat meningkatkan kualitas layanan jika dialokasikan untuk memotivasi kinerja agen melalui pemberian insentif. Pada bidang praktis penelitian ini berkontribusi dalam mengevaluasi aturan mengenai penggunaan dana kapitasi, memberikan gambaran mengenai pengelolaan dana kapitasi di level puskesmas. Dari gambaran tersebut para pihak yang terlibat dalam meningkatan layanan kesehatan bisa meperbaiki kinerjanya.

Penelitian ini hanya dilakukan di puskesmas dengan proporsi pendapatan dana kapitasi yang tinggi, sehingga hasil penelitian belum bisa merepresentasikan seluruh puskesmas yang ada di Indonesia. Perlu dilakukan penelitian dengan proporsi dana kapitasi yang rendah. Peneliti tidak melakukan interview tentang penggunaan dana kapitasi. Jadi hasil yang diperoleh kurang mendalam tentang kemana saja dana kapitasi dialokasikan. Misalnya pada tindakan preventif, pembelian sarana dan prasarana kesehatan atau pembayaran jasa layanan. penelitian ini menggunakan laporan kinerja yang dibuat oleh masing-masing puskesmas untuk menilai kualitas layanan. laporan tersebut dibuat dan dinilai sendiri oleh puskesmas, sehingga memungkinkan penilaian yang bias. Oleh sebab itu diharapkan kepada penelitian selanjutnya untuk melakukan survei secara langsung kepada pasien guna memperoleh penilaian kualitas layanan yang lebih objektif.

\section{DAFTAR PUSTAKA}

Andoh-Adjei, Francis-Xavier, Ernst Spaan, Felix A Asante, Sylvester A Mensah, and Koos Van Der Velden. 2016. "A Narrative Synthesis of Illustrative Evidence on Effects of Capitation Payment for Primary Care: Lessons for Ghana and Other Low/middleIncome Countries." Ghana Med J 50 (504):207-19. https://doi.org/10.4314/gmj. v50i4.3.

Atkinson, A.A., R.D. Banker, R.S. Kaplan, dan S.M. Young. 2000. Management Accounting. New Jersey: Prentice Hall

Bastian, Indra. 2018. Akuntansi Kesehatan. Penerbit Erlangga: Jakarta

Bonner, S.E. dan G. B. Sprinkle. 2002. The Effects of Monetary Incentives on Effort and Task Performance: Theories, Evidence, and A Framework for Research. Accounting, Organizations, and Society 27; 303- 345.

Eisenhardt, K. M. 1989. Agency Theory. An Assessment And Review. Academy Of Management Review, 14(1): 57-74. evidence in general practice. Scandinavian Journal of Primary Health Care, 2013; 31: 56-63

Ghozali, Imam. 2011. Aplikasi Analisis Multivariate Dengan Program IBM SPSS 19. 5thed. Semarang: Badan Penerbit UNDIP. 
Indah Shofiyah, Indra Bastian | Pengaruh Dana Kapitasi dalam Peningkatan Kualitas Layanan ...

Goodson, John D, Arlene S Bierman, Oliver Fein, Kimberly Rask, Eugene C Rich, and P Harry. 2001. "The Future of Capitation The Physician Role in Managing Change in Practice."

Gronroos, Christian. 1990. Service Management and Marketing. Toronto: Lexington Books. Handoko, M. 1992. Motivasi Daya Penggerak Tingkah Laku. Yogyakarta: Kanisius.

Hasan Abdul Ghani, Sasmito. 2016. Policy Analysis Of Used Capital Fund Of Jkn Inprimary Healthcare In Bogor In 2016. Departemen Administrasi dan Kebijakan Kesehatan. FKM. UI

http://www.who.int/entity/rhl/effective_practice_and_organizing_care/cd008451/en/. Jacob, Paul, Till Bärnighausen, Aurélia Souares, Adama Traoré, Brice Bicaba, Ali Sié, and Rainer Sauerborn. 2014. "Social Science \& Medicine Provider Payment Methods and Health Worker Motivation in Community-Based Health Insurance : A Mixed-Methods Study" 108:2013-15.

Jegers, Marc, Katrien Kesteloot, Diana De Graeve, and Willem Gilles. 2002. "A Typology for Provider Payment Systems in Health Care.” Health Policy 60 (3):255-73. https:// doi.org/10.1016/S0168-8510(01)00216-0.

Jensen, M. C and Meckling, W.H. 1976. Theory of the Firm : Managerial Behavior, Agency Costs and Ownership Structure . "Journal of Financial Economics", Oktober, 1976, V. 3, No. 4, pp.305-360.

Kemenkes. (2009). Sistem kesehatan nasional: Jakarta.

Kemenkes. (2014). Permenkes no. 28 tahun 2014 tentang Pedoman Pelaksanaan Program Jaminan Kesehatan Nasional.

Kemenkes. (2015). Jumlah Puskesmas per Juni 2015 menurut Propinsi dan Kabupaten/ Kota. Retrieved from http://www.depkes. go.id/download.php?file=download/ pusdatin/ lain- lain/JumlahPuskesmas 30 Juni 2018.pdf

Kementrian kesehatan. 2016. Peraturan Menteri Kesehatan Republik Indonesia Nomor 21 Tahun 2016 Tentang Penggunaan Dana Kapitasi Jaminan Kesehatan Nasional Untuk Jasa Pelayanan Kesehatan Dan Dukungan Biaya Operasional Pada FKTP Milik Pemerintah Daerah. Kementrian Kesehatan RI.

KPK. (2015). KPK Temukan 4 Kelemahan Pengelolaan Dana Kapitasi. Retrieved from https:// www.kpk.go.id/id/berita/siaranpers/ 2440-kpk-temukan-4-kelemahanpengelolaandana-kapitasi

Majeed, Azeem. 2002. "Risks and Benefits of the Use of Capitation Formulae in Primary Care." Disease Management and Health Outcomes 10 (4):215-20. https://doi. org/10.2165/00115677-200210040-00002.

Muntlin A, Gunningberg L, Carlsson M. Patients perceptions of quality of care at an emergency department and identification of areas for quality improvement. J Clin Nurs 2006;15(8):1045-1056

Ninot, G., G. Moullec, M. C. Picot, A. Jaussent, M. Hayot, M. Desplan, J. F. Brun, J. Mercier, and C. Prefaut. 2011. "Cost-Saving Effect of Supervised Exercise Associated to COPD Self-Management Education Program.” Respiratory Medicine105(3

Jurnal REKSA: Rekayasa Keuangan, Syariah, dan Audit, Vol. 07, No. 02, 2020, pp 85-101| 100 
Indah Shofiyah, Indra Bastian | Pengaruh Dana Kapitasi dalam Peningkatan Kualitas Layanan ...

Palino. Delvianty. 2017.Analisis Pemanfaatan dana Kapitasi dalam meningkatkan Mutu Layanan pada Puskesmas Makale. Fakultas Ekonomika dan Bisnis UGM

Parasuraman, A, Berry, L.L, Zeithaml, V.A. 1990. Refinement and reassessment of the SERVQUAL scale. Journal of Retailing, Vol. 67 No

Pearson, W. S., D. E. King, and C. Richards. 2013. "Capitated Payments to Primary Care Providers and the Delivery of Patient Education." The Journal of the American Board of Family Medicine 26 (4):350-55.

Pemerintah Republik Indonesia. Peraturan Badab penyelenggara jaminan sosial Nomor 2 Tahun 2015 tentang norma penetapan besaran kapitasi dan pembayaran kapitasi berabasis pemenuhan komitmen pelayanan pada fasilitas kesehatan tingkat pertama

Pemerintah republik indonesia. Peraturan menteri Kesehatan Nomor 21 Tahun 2016 tentang Penggunaan dana kapitasi jaminan kesehatan nasional untuk jasa pelayanan kesehatan dan dukungan biaya operasional pada fasilitas kesehatan tingkat pertama milik pemerinatah daerah

Pemerintah republik Indonesia. Peraturan Presiden Nomor 32 Tahun 2014 tantang pengelolaan dan pemanfaatan dana kapitasi jaminan kesehatan nasional pada fasilitas kesehatan tingkat pertama milik pemerintan daerah

Pemerintah republik Indonesia. Undang-undang Nomor 24 Tahun 2011 Tentang Badan Penyelenggara Jaminan Sosial

Pemerintah republik Indonesia. Undang-undang Nomor 25 Tahun 2009 Tentang Pelayanan Publik

Pemerintah republik Indonesia. Undang-undang Nomor 40 Tahun 2004 Tentang Sistem Jaminan Sosial Nasional (SJSN)

Pine, Michael, Roger J Meimban, and Gregory J Pine. 2010. “C 862 |.” October 48 (10):86268.

Prasojo, Eko. 2006. Reformasi Birokrasi di Indonesia: Beberapa Catatan Kritis. Jurnal Ilmu Admnistrasi dan Organisasi, Bisnis \& Birokrasi, Volume 14, Nomor 1 (Januari).

Robinson, J C. 2001. "Theory and Practice in the Design of Physician Payment Incentives.” The Milbank Quarterly 79

Rosenthal, Frank . 2006. What is the empirical basis for paying for quality in health care?. Med Care Res Rev.

Scott, A, P Sivey, and D Ait Ouakrim. 2011. "The Effect of Financial Incentives on the Quality of Health Care Provided by Primary Care Physicians.

Sinambela, Lijan Poltak. 2006. Reformasi Pelayanan Publik, Teori, Kebijakan dan Implementasi. Jakarta: PT Bumi Aksara

Sugiyono. 2007. Statistika Untuk Penelitian. Bandung: Alfabeta.

Van Djik et al. 2014. Impact of remuneration on guideline adherence: Empirical. Scandinavian Journal of Primary Health Care, 2013; 31: 56-63 